DOI: 10.17707/AgricultForest.63.3.07

\begin{abstract}
Mykola NAZARENKO, Yuri LYKHOLAT, Ivan GRIGORYUK, Nina KHROMYKH ${ }^{1}$
\end{abstract}

\title{
CONSEQUENCES OF MUTAGEN DEPRESSION CAUSED BY DIMETHILSULFATE
}

\begin{abstract}
SUMMARY
The strategy of investigation combined the effects of mutation depression evident at first generation on cell and plant level and peculiarities of recurrent mutagen action. The main purposes of investigations in this area were determination genotype-mutagen interaction for modern Ukrainian winter wheat varieties, identify sensitive of genotypes for DMS (dimethylsulfate) genotypes and evolution repeat action of mutagen as a method in difference alteration on firs step of mutation breeding program, which limited next stages by quantity of material for breeding. Here we report cytogenetic, plant growth and development characteristics of mutation induction variability of the new wheat varieties and some relationships between means of plants grows and developments, morphometrical parameters, cytogenetic characteristics and different concentrations and types of mutagens at first generation after DMS action.
\end{abstract}

Keywords: chemical mutagenesis, winter wheat, dimethylsulfate, chromosomal aberrations.

\section{INTRODUCTION}

DMS (dimethylsulfate) as a mutagen is widely used for special investigations in plant genetics structure, it the one of the most often used for reverse genetic approach mutagens in modern functional genomics (other exploited substance is related to DMS (in the same group of chemical mutagens) ethilmethansulfate (EMS) and for programs for genetic improving indigenous cultivars in South-East Asia (FAO-IAEA programs for coordinating investigations in chemical mutagens) (Shu et al, 2011). DMS as a mutagen factor is traditionally related to the same family of mutagens (supremutagens), which used in our previous investigations due to mechanism of action on DNA-level, but with a little distinguishes (Jankowicz-Cieslak et al, 2017).

\footnotetext{
${ }^{1}$ Mykola Nazarenko (corresponding author: nik_nazarenko@ukr.net), Department of Plant Breeding and Seeds Management, Faculty of Agronomy, Dnipropetrovsk State Agrarian and Economic University, Dnipro, UKRAINE; Yuri Lykholat, Nina Khromykh, Department of Plant Physiology and introduction, Faculty of Biology, Oles Honchar Dnipropetrovsk National University, Dnipro, UKRAINE; Ivan Grigoryuk, Department of Plant Physiology and Biochemistry, Bioenergetics, National University of Life and Environmental Sciences of Ukraine, Kyiv, UKRAINE.

Notes: The authors declare that they have no conflicts of interest. Authorship Form signed online.
} 
Mutagen effects on cell and whole plant level (named as mutagen depression) are the key factors which limited either winter wheat productivity for agricultural purpose at first generation (due to some modern investigations at next generations too (Mangi et all, 2016) or quantity of materials obtained for next stapes of mutation breeding programs after mutagen action for identification and selection of mutants. Consequences of mutagen action on cell level (chromosomal aberrations) are closely connected with future mutations rate. Influence of mutagen factors action is depended on next parameter: physiological parameter of mutagen action object, genotype of object, type of mutagen action (acute, chronicle), nature of mutagen, doses or concentration of mutagen, fractional of dose or concentration, time of exposure, concentration or appearance of free active oxygen, temperature and other environmental conditions (Zhang et al, 2015; Nazarenko, Kharytonov, 2016).

This article is a part of our investigation of recurrent mutagen treatment of winter wheat varieties. In previous parts we developed effects of genotypemutagen interaction after gamma-ray irradiation and nitrosomethilurea (NMU) nitrosoethilurea (NEU), 1,4- bisdiazoatsetilbutan (DAB) (Nazarenko, 2017a; Nazarenko et al, 2017)

Recurrent mutagenesis includes the exposure to mutagen action of progeny of plants that had been treated in previous generation. The strategy of treating the progeny of previously treated plants is well-known as recurrent action. Investigators studied a wide range of mutagens including different types of physical mutagens (different types of radiation) and the chemical mutagen (EMS); the alternation of EMS with irradiation was also studied. The results of these experiments did not bear out the expected results and were at best mixed. In most cases, radiosensitivity, mutation rate and spectra remained unaffected with repeated irradiation of subsequent generations. In our investigations we used other types of chemical mutation factors (nitrosoalkylureas, DAB, DMS) and alteration these mutagens with gamma-rays. We obtained new results according to reduce radiosensetivity, mutagen depression after recurrent mutagenesis and determined some new laws for recurrent mutagen action. In case of mutagen alteration we ran on with trivial, normal reaction on mutagen action (Chaima et al, 2012, Nazaenko, 2017b).

DMS are related to special group of mutagens "supermutagens" too (as classified by Rapoport). Special ability of this group is induction mutations on level of comparable mutagen without high damages, which influence on survival ability of plant material (Jovtcheva et al, 2002; Özel et al, 2015). Supermutagens induct 50-60 times more mutations than relevant by their consequences for surviving and plant development doses of gamma rays or fast neutrons (Albokari, 2014). But DAB in spite of previous chemical mutagens (nitrosoalkylureas), by its action more similar to physical mutagens (like as gamma-rays) than for other chemical mutagens and don't so site-specific.

Other feature (general for all chemical mutagens) is induction of gen mutations on peculiar DNA-sequence rather than structural changes. It is depends 
on chemical nature of specific mutagen. That's why chemical mutagenesis is one of the important methods for modern genetics investigations (as for example for reverse genetics, for different types of tilling's methods). We can predict (in certain limits) more probably types of future mutations with higher rates (according to preferable DNA sequences for mutagen action) (JuchimiukKwasniewska, 2002; Natarajan, 2005).

Mutagenic effects of chemicals have been assessed by both analysis of chromosomal aberrations (Rakhmatullina and Sanamyan, 2007) and investigation plant development and grows at first generation under field conditions.

Parameters traditionally used to estimate the degree of plant injury in the $\mathrm{M}_{1}$ generation are: 1 . Seedling height, determined at a particularly stage soon after germination. 2. Root length, determined soon after germination in controlled environment conditions. 3. Emergence under field conditions or germination. 4. Survival under field or controlled environment conditions. 5. Number of florets, flowers or inflorescences per plant. 6. Number of florets or flower parts per inflorescence. 7. Number of seed set. 8. Number of seeds per plant (Khaled et al, 2016; Jankowicz-Cieslak et al, 2017).

Mutated plants typically show reduced fertility, mainly caused by chromosomal changes during meiosis. Plant surviving, pollen fertility and yield structure were studied for identification of mutagen depression evident at first generation (Karthika and Subba, 2006; Nazarenko, 2016; Nazarenko, 2017b).

Analysis of variability of chromosomal aberrations after mutagen action of any type of mutagens by anaphases method is one of the well-known and the most precision methods which we can exploited for determine fact of mutagen action, identify nature of mutagen. For example, this method is widely used as for determine of radionuclide's pollution of environment, its level, danger of this pollution as for identification optimal doses of radiation and concentrations of chemical mutagens in breeding practice. A relation amid clastogenic adaptation shown in descending of chromatid type of changes, micronuclei and changes in number of chromosomes in cells, and the clastogenic effect has been appeared (Rakhmatullina and Sanamyan, 2007). For crops like wheat, individual tillers (side branches) originate from different cells of the embryo of the treated seeds. If an aberration occurs in one of these cells, it will be carried in the tiller developed from that cell. Influence of different types of chemical mutagens or any type ionizing radiation according to this method can be analyzed by summarized number and kinds of chromosomal damages. Changes in chromosome number and structure in mitotic cells is initiated after mutagen action. Chromosomal changes rank from breaks, through exchanges, laggards and anaphase bridges, dicentric and centric ring formations, terminal fragments with telomeric signal at only one end and interstitial fragments that appear as double minutes without any telomeric signals changes in irradiated mitotic cells (Rakhmatullina, 2007). Both structural and numerical aberrations occur spontaneously due to intraneous and extraneous factors and appear in terms of last mitotic cell division phases (Nikolova et al, 2015). 
The main purposes of investigations in this area were determination genotype-mutagen interaction for modern ukrainian winter wheat varieties, identify less sensitive for DMS genotypes and evolution repeated mutagenesis as a method in difference alteration on firs step of mutation breeding program, which limited next stages by quantity of material for breeding.

\section{MATERIAL AND METHODS}

Seeds of (in brackets method of obtaining varieties or used mutagens) Favoritka, Lasunya, Hurtovina (irradiation of initial material by gamma rays), line 418, Kolos Mironovschiny (field hybridization), Sonechko (chemical mutagenesis, nitrosodimethilurea (NDMU) 0.005\%) and Kalinova (chemical mutagenesis, DAB 0.1\%), Voloshkova (termomutagenesis - low plus temperature at plant development stage of vernalizaion has been used as mutagen factor) of winter wheat (Triticum aestivum L.) were subjected to chemical mutagen dimethylsulfate (DMS) - 0.0125, 0.025 and $0.05 \%$ presoaked. Each treatment was comprised of 1000 wheat seeds. Exposition of chemicals mutagens was 18 hours. These concentrations and exposure are optimal for the breeding process that has been repeatedly established earlier. (Ahloowalia et al, 2004; Nazarenko, 2016). Non-treated varieties were used as a check for each variety.

Treated seeds were sown in rows with inter and intra-row spacing of 50 and $15 \mathrm{~cm}$, respectively, to raise the $\mathbf{M}_{1}$ population. $\mathbf{M}_{1}$ plant rows were grown in three replications with check-rows of untreated varieties in every ten-row interval. Data on seed germination and surviving plants were recorded considering whole plots of $\mathrm{M}_{1}$ population. Data on yield structure components (plant height, general number of culms, number of productive culms, spike length, spikelets per spike, number of grain per spike, grain weight per spike and plant, 1000 grains weight) were taken from 50 randomly selected plants of each treatment representing more or less all types of morphological plants (Sanamyan et al, 2010).

The seeds used in this study were of the $\mathrm{M}_{0}$ generation. After mutagen treatment dry seeds were germinated in Petri dishes under $24-72$ hours (depends on presoaking and mutagen action), temperature $+25^{\circ} \mathrm{C}$. After wards central primary roots were cut and fixed in solution of alcohol and acetic acid (in proportion 3:1) for 24 hours. Fixation material was stored in $70 \%$ alcohol solution under temperature $2{ }^{\circ} \mathrm{C}(20-25$ roots per variant). Cytological analysis was carried out by the standard method at temporary press-time preparations of root tips $(1-1.5 \mathrm{~mm})$ stained with acetocarmine (has been prepared by Remsderh). Tissue maceration (if it needs for analysis) was carried out at $45 \%$ solution of acetic acid (during 5 minutes on bane-marie under $60^{\circ} \mathrm{C}$ ). Anaphase of cell division was observed by light microscope JNAVAL. No less than 500 cells in proper phases of mitosis (anaphase) were observed in each variant, number of samples were about 20 - 25 per variant (Lifang et al, 2001; Rank et al, 2002; Natarajan, 2005; Nikolova et al, 2015).

Mathematical processing of the results was performed by the method of analysis of variance, the variability of the mean difference was evaluated by 
ANOVA. Used the standard tools of the program Statistica 8.0 for factor and discriminant analysis (ANOVA module).

\section{RESULTS AND DISCUSSION Analysis of grows and development of plants}

In $\mathrm{M}_{1}$ population, observations were recorded seed germination and plant surviving, pollen fertility (table $1-2$ ) , plant height, spikes/plant, spike length, kernels/spike, 1000-grain weight, yield/plant. Standard error $( \pm \mathrm{SE})$ values of the treated populations are at tables too.

The results on germination of seeds, survival rate of plants derived from treated and untreated seeds are tabulated (Table 1). Germination and survival abilities of seeds reduce compared to untreated seeds and previous variant in all cases with statistical significance.

Plant survival ability ranges from 76 (Kolos Mironivschini, Voloshkova) to $73 \%$ (Hurtovina, Favoritka) at DMS $0.0125 \%$ and from 45 (Hurtovina) to 38 $\%$ (Line 418) at DMS $0.05 \%$, while it ranged from 98 to $92 \%$ under untreated control. Concentration of DMS 0.05 was semilethal.

In general, the correlation between the concertation value and survival abilities of plants is on least level from other mutagens (-0.89).

Table 1. Main parameters of grown of winter wheat plants at $\mathrm{M}_{1}$ generation

\begin{tabular}{|l|c|c|c|c|}
\hline \multicolumn{1}{|c|}{ Trial } & $\begin{array}{c}\text { Germination, } \\
\%\end{array}$ & $\begin{array}{c}\text { Survival after } \\
\text { winter, \% }\end{array}$ & $\begin{array}{c}\text { Germination, } \\
\%\end{array}$ & $\begin{array}{c}\text { Survival after } \\
\text { winter, \% }\end{array}$ \\
\hline \multicolumn{1}{|c|}{ Variety } & \multicolumn{2}{|c|}{ Kolos Mironivschini } & \multicolumn{2}{c|}{ Kalinova } \\
\hline Check & $98 \pm 0.57$ & $91 \pm 0.93$ & $94 \pm 0.94$ & $88 \pm 0.98$ \\
\hline DMS 0.0125\% & $76 \pm 0.88^{*}$ & $76 \pm 0.96^{*}$ & $77 \pm 0.99^{*}$ & $75 \pm 1.10^{*}$ \\
\hline DMS 0.025\% & $65 \pm 0.72^{*}$ & $65 \pm 0.64^{*}$ & $67 \pm 1.82^{*}$ & $64 \pm 1.23^{*}$ \\
\hline DMS 0.05\% & $41 \pm 0.47^{*}$ & $40 \pm 0.43^{*}$ & $45 \pm 1.10^{*}$ & $42 \pm 0.98^{*}$ \\
\hline Variety & \multicolumn{5}{|c|}{ Voloshkova } & \multicolumn{2}{c|}{ Sonechko } \\
\hline Check & $92 \pm 0.57$ & $87 \pm 0.93$ & $94 \pm 0.94$ & $89 \pm 0.98$ \\
\hline DMS 0.0125\% & $77 \pm 1.03^{*}$ & $76 \pm 0.85^{*}$ & $75 \pm 1.11^{*}$ & $74 \pm 0.98^{*}$ \\
\hline DMS 0.025\% & $64 \pm 0.88^{*}$ & $63 \pm 1.20^{*}$ & $68 \pm 0.43^{*}$ & $66 \pm 0.63^{*}$ \\
\hline DMS 0.05\% & $40 \pm 1.12^{*}$ & $39 \pm 1.17^{*}$ & $40 \pm 0.34^{*}$ & $40 \pm 0.82^{*}$ \\
\hline Variety & \multicolumn{3}{|c|}{ Favoritka } & \multicolumn{2}{c|}{ Hurtovina } \\
\hline Check & $98 \pm 0.57$ & $91 \pm 0.93$ & $92 \pm 0.94$ & $84 \pm 0.98$ \\
\hline DMS 0.0125\% & $73 \pm 0.84^{*}$ & $73 \pm 1.13^{*}$ & $74 \pm 0.93^{*}$ & $73 \pm 0.73^{*}$ \\
\hline DMS 0.025\% & $68 \pm 0.92^{*}$ & $67 \pm 1.26^{*}$ & $61 \pm 1.07^{*}$ & $60 \pm 0.97^{*}$ \\
\hline DMS 0.05\% & $45 \pm 0.67^{*}$ & $44 \pm 2.13^{*}$ & $47 \pm 0.65^{*}$ & $45 \pm 1.08^{*}$ \\
\hline Variety & \multicolumn{3}{|c|}{ Lasunya } & \multicolumn{2}{c|}{ Line 418} \\
\hline Check & $98 \pm 0.57$ & $94 \pm 0.93$ & $93 \pm 0.94$ & $92 \pm 0.98$ \\
\hline DMS 0.0125\% & $75 \pm 0.80^{*}$ & $74 \pm 1.16^{*}$ & $76 \pm 1.02^{*}$ & $74 \pm 0.67^{*}$ \\
\hline DMS 0.025\% & $68 \pm 1.00^{*}$ & $67 \pm 0.95^{*}$ & $64 \pm 1.12^{*}$ & $62 \pm 0.33^{*}$ \\
\hline DMS 0.05\% & $41 \pm 1.36^{*}$ & $39 \pm 0.34^{*}$ & $39 \pm 1.13^{*}$ & $38 \pm 0.92^{*}$ \\
\hline
\end{tabular}

* - difference is statistically significance from check at $\mathrm{P}_{0.05}$ 
Correlation between the concentration of mutagens and pollen fertility was -0.82 (table 2). It was significantly higher in comparison to other chemical mutagens. For some varieties such as Hurtovina, line 418 there were not statistically difference between DMS $0.0125 \%$ and untreated check. As we can see from these tables parameters of surviving and pollen fertility are responsible for mutagen action (in spite of $\mathrm{DAB}$ ) and suitable for evolution mutagen depression in case this mutagen.

Table 2. Pollen fertility after mutagen action, \%

\begin{tabular}{|c|c|c|c|c|c|c|c|c|}
\hline Trial & 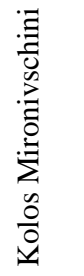 & 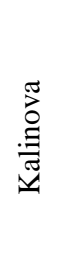 & $\begin{array}{l}\frac{\pi}{3} \\
\frac{0}{7} \\
\frac{1}{n} \\
0 \\
0 \\
0\end{array}$ & 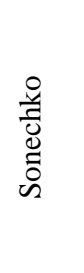 & 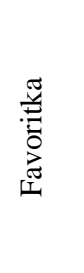 & $\begin{array}{l}\text { 莟 } \\
\text { 总 } \\
\text { 总 }\end{array}$ & 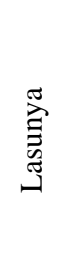 & $\begin{array}{l}\infty \\
\exists \\
\stackrel{\sim}{\exists} \\
. 尹\end{array}$ \\
\hline Check & 95.0 & 93.1 & 89.7 & 96.7 & 95.7 & 98.6 & 96.8 & 93.0 \\
\hline DMS 0.0125\% & 93.8 & $89.8^{*}$ & $82.3^{*}$ & $83.0^{*}$ & $80.0^{*}$ & $85.3^{*}$ & $83.1^{*}$ & $83.6^{*}$ \\
\hline DMS 0.025\% & $92.0^{*}$ & $83.7^{*}$ & $77.3^{*}$ & $78.6^{*}$ & $75.7 *$ & $78.6^{*}$ & $70.9^{*}$ & $70.2^{*}$ \\
\hline DMS $0.05 \%$ & $88.7^{*}$ & $78.0^{*}$ & 69.1* & $71.2^{*}$ & $65.2^{*}$ & $64.7^{*}$ & $62.6^{*}$ & $58.3^{*}$ \\
\hline
\end{tabular}

All parameters of the crop yield structure have been studied. Components such as plant height, 1000 grain weight, grain weight per plant, number of grains per spike, grain weight per spike, general number of culms, number of productive culms, spike lengths have been developed. Only four (plant height, grain weight per spike, grain weight per plant and 1000 grain weight) showed statistically difference level of mutagen depression under any concentration action.

Regarding the plant height, correlation between the concentration and the indicator constituted -0.82, (high invert correlation). This parameter decreases if the concentration increases. Gradual decrease in height is a tendency for all varieties.

Table 3. Correlation between DMS concentrations and some components of yield structure of $\mathrm{M}_{1}$ varieties

\begin{tabular}{|l|c|c|c|c|c|c|c|c|}
\hline Parameter & $\begin{array}{c}\text { Plant } \\
\text { height }\end{array}$ & $\begin{array}{c}\text { Number } \\
\text { of culms }\end{array}$ & $\begin{array}{c}\text { Spike } \\
\text { lengths }\end{array}$ & $\begin{array}{c}\text { Number } \\
\text { of } \\
\text { spikelets }\end{array}$ & $\begin{array}{c}\text { Number } \\
\text { of grains } \\
\text { per spike }\end{array}$ & $\begin{array}{c}\text { Grain } \\
\text { weight } \\
\text { per } \\
\text { spike }\end{array}$ & $\begin{array}{c}\text { Grain } \\
\text { weight } \\
\text { per } \\
\text { plant }\end{array}$ & $\begin{array}{c}1000 \\
\text { grain } \\
\text { weight }\end{array}$ \\
\hline Concentr. & -0.82 & -0.22 & 0.8 & -0.05 & -0.64 & -0.82 & -0.71 & -0.91 \\
\hline
\end{tabular}

The indicator of grain weight per spike was informative in case of DMS at all concentrations. The correlation coefficient was -0.82 . 
The indicator of grain weight per plant was not so reliable and sometimes in case of low concentration (DMS 0.0125 \%) mutagen depression hasn't been appeared. The correlation coefficient was -0.71 .

The thousand grain weight is the most reliable for mutagen depression evaluation (similar as other mutagens). We observed depression in all variants. The correlation coefficient was -0.91 (similar to gamma-rays).

No one variety was statistically more sensitive to DMS action, for all varieties mutagen depression by morphometric parameters was on the comparable level.

\section{Chromosomal aberrations analysis}

At table 4 we represent dates of the results of next parameters analyzed: general number of observing mitosis in primary roots tips, number of cells in appreciate phase with visible chromosomal aberrations rearrangements, total rate of chromosomal aberrations. Standard error ( \pm SE) values of the treated variants are shown at table 1 too. As we can see from table 1 frequencies of aberrations were changed from 9,96 \% (Lasunya, DMS 0,0125 \%) to 29,98 \% (line 418, DMS 0,05 \%) percent from total number of cells in division in experimental microscope samples. All the variants are statistically substantially dissimilar from each other and from the check.

In spite of previous investigation level of rates of aberrations in any cases peculiar to varieties obtained by chemical mutation breeding (Sonechko, Kalinova) didn't differ from other varieties and we can predict that rates of mutations at next generations wouldn't change. The higher frequency of aberrations has been obtained by used DMS $0.05 \%$ as usual. It gives us a possibility to conclude about high level of specific of genotype-mutagen interaction (for chemical mutagens) and confirm that only sensitive to chemical mutagen (or very closely related by nature) which used for obtaining this genotype is lower under re-exposure.

Rates of chromosomal aberrations in all cases were on comparable level. No one variety didn't stand out against other. Influence of DMS is compared with gamma-rays (in spite of other chemical mutagens) and, not only by aberration rates, but by parameters of spectra of chromosomal aberrations is very similar to gamma-irradiated. We can range mutagens in next sequence by its genetic activity (from least to pick) DAB $\rightarrow$ NEU $\rightarrow$ NMU $\rightarrow$ gamma-rays, DMS.

From the Table 3 we can see that we cannot identify in any way varieties or group of varieties more or less sensitive to DMS action. Changeability on cell level was on comparable mean for all genotypes. Distinct from previous investigation not recurrent, only repeat mutagen action doesn't depend on object genotype. We developed next types of aberrations of chromosomes after investigation of spectra in our samples: chromosomal bridges and doublebridges, fragments of chromosomes and double-fragments, micronucleus, lagging chromosomes. Cases with complicated aberrations (two or more kinds of changes 
in one mitosis) and ratio fragments till bridges were counted up singly (Table 4). Number of any type of chromosomal changes was leaped with concentration ascended (correlation coefficients is on 0,87 - significantly higher than for other chemical mutagens, comparable with gamma-rays). In this case, like as nitrosoalkylureas and DAB, more fragments and double-fragments were caused by DMS (fragments-bridges ratio more than 1), except variants with difference concentration of DMS, which depends on genotype (variety) (Nazarenko, Kharitonov, 2016; Nazarenko, 2017b; Nazarenko et al, 2017). But in the most cases we will be able to use this parameter for identify difference between gamma-rays action and chemical mutagenesis in case of unknown mutagen factor.

Table 4. Frequency of chromosomal aberrations in $\mathrm{M}_{1}$ generation of winter wheat varieties

\begin{tabular}{|c|c|c|c|c|c|c|}
\hline \multirow{3}{*}{ Variable } & \multirow{2}{*}{$\begin{array}{l}\text { Mitosis, } \\
\text { number }\end{array}$} & \multicolumn{2}{|c|}{$\begin{array}{c}\text { Chromosomal } \\
\text { aberrations }\end{array}$} & \multirow{2}{*}{$\begin{array}{l}\text { Mitosis, } \\
\text { number }\end{array}$} & \multicolumn{2}{|c|}{$\begin{array}{c}\text { Chromosomal } \\
\text { aberrations }\end{array}$} \\
\hline & & n. & $\%$ & & $\mathrm{n}$. & $\%$ \\
\hline & \multicolumn{3}{|c|}{ Favoritka } & \multicolumn{3}{|c|}{ Line 418} \\
\hline Check & 984 & 19 & $1.93 \pm 0.31$ & 962 & 11 & $1.14 \pm 0.11$ \\
\hline DMS 0.0125\% & 1001 & 127 & $12.69 \pm 1.14^{*}$ & 850 & 85 & $10.00 \pm 0.98 *$ \\
\hline DMS 0.025\% & 911 & 174 & $19.09 \pm 1.33^{*}$ & 939 & 178 & $18.96 \pm 1.38 *$ \\
\hline \multirow[t]{2}{*}{ DMS $0.05 \%$} & 564 & 147 & $26.06 \pm 1.64^{*}$ & 1009 & 302 & $29.98 \pm 1.87 *$ \\
\hline & \multicolumn{3}{|c|}{ Lasunya } & \multicolumn{3}{|c|}{ Hurtovina } \\
\hline Check & 1056 & 15 & $1.42 \pm 0.19$ & 1034 & 12 & $1.16 \pm 0.11$ \\
\hline DMS $0.0125 \%$ & 1004 & 100 & $9.96 \pm 0.92 *$ & 1010 & 110 & $10.89 \pm 1.02 *$ \\
\hline DMS 0.025\% & 1017 & 163 & $16.02 \pm 1.28 *$ & 895 & 161 & $17.99 \pm 1.39 *$ \\
\hline \multirow[t]{2}{*}{ DMS $0.05 \%$} & 717 & 166 & $23.14 \pm 1.49 *$ & 581 & 142 & $24.44 \pm 1.59 *$ \\
\hline & \multicolumn{3}{|c|}{ Sonechko } & \multicolumn{3}{|c|}{ Voloshkova } \\
\hline Check & 1026 & 8 & $0.78 \pm 0.04$ & 1003 & 31 & $3.09 \pm 0.34$ \\
\hline DMS $0.0125 \%$ & 1014 & 101 & $9.96 \pm 0.98 *$ & 1016 & 104 & $10.23 \pm 1.01^{*}$ \\
\hline DMS 0.025\% & 985 & 145 & $14.72 \pm 1.14 *$ & 892 & 153 & $17.16 \pm 1.30 *$ \\
\hline \multirow[t]{2}{*}{ DMS $0.05 \%$} & 509 & 99 & $19.45 \pm 1$ и. $31^{*}$ & 511 & 129 & $25.25 \pm 1.49 *$ \\
\hline & \multicolumn{3}{|c|}{ Kalinova } & \multicolumn{3}{|c|}{ Kolos Mironivschini } \\
\hline Check & 1047 & 9 & $0.86 \pm 0.11$ & 909 & 10 & $1.10 \pm 0.13$ \\
\hline DMS $0.0125 \%$ & 1010 & 101 & $10.00 \pm 1.01 *$ & 1040 & 124 & $11.92 \pm 1.08 *$ \\
\hline DMS 0.025\% & 917 & 157 & $17.12 \pm 1.24^{*}$ & 892 & 173 & $19.40 \pm 1.46^{*}$ \\
\hline DMS $0.05 \%$ & 649 & 137 & $21.11 \pm 1.41^{*}$ & 639 & 177 & $27.70 \pm 1.74 *$ \\
\hline
\end{tabular}

* - difference statistically significant on $\mathrm{P}_{0,01}$ 
Number of complicated (or combined) aberrations was significantly higher as well as micronucleus and lagging chromosomes then for previous mutagens. Moreover, in some cases number of complicated aberrations was more than for gamma-rays. But for some varieties we cannot observe any difference with this parameter between DMS 0,025 \% and 0,05\%. Generally, when concentration of DMS was increased the rate of fragments and bridges also has increased. Complicated aberrations for this type of action is a value parameter for mutagen influence evaluation. Significance of parameters was satisfied by discriminant analyze (table 5).

Table 5. Results of discriminant analysis parameters of rate and spectra of chromosomes rearrangements

\begin{tabular}{|l|c|c|c|}
\hline Parameter in model & $\lambda$ & $\begin{array}{c}\text { F-remove } \\
(4,51)\end{array}$ & p-level \\
\hline Rate of aberrations & 0.61 & 9.01 & 0.00 \\
\hline Fragments (single and double) & 0.44 & 7.12 & 0.01 \\
\hline $\begin{array}{l}\text { Bridges (chromosome and } \\
\text { chromatide) }\end{array}$ & 0.31 & 6.03 & 0.02 \\
\hline Micronucleus, lagging chromosomes & 0.07 & 0.89 & 0.35 \\
\hline Complicated aberrations & 0.22 & 5.83 & 0.04 \\
\hline
\end{tabular}

The results of two-factor analysis ("genotype" and "concentration" shown us that, prevalently, on the rate of chromosome aberrations factor "concentration" influenced, the "genotype". Genotype strong influenced on parameter fragments/bridges ratio $\left(\mathrm{F}=18.92 ; \mathrm{F}_{\mathrm{cr}}=4.92 ; \mathrm{p}\right.$-level 0.01; $\mathrm{F}=12.64 ; \mathrm{F}_{\mathrm{cr}}=4.92$; p-level 0.01).

Thus, we developed that repeated exposure to the other mutagen (DMS on the variety obtained by the action of other mutagen) doesn't lead to important difference between genotypes.

Thereby, investigation of DMS action confirmed reliability of fragmentsbridges ratio (prevalence of fragments under bridges for chemical mutagens and vise versa for gamma-rays) for mutagen nature identification. Complicated (or combined) aberrations is a valuable parameter for dose evaluation under DMS action. Genotype-mutagen interaction has been shown in bridge - fragments ratio. Previous rules for other mutagens were confirmed for DMS (with some peculiarities).

\section{CONCLUSIONS}

The most informative parameters to determine the degree of mutagenic depression in the first generation for plant growth and development were germination and survival rates, pollen sterility, grain weight per spike, 1000 grain weight, less reliable grain weight per plant. Therefore, chemical mutation varieties are not sensible for to repeated action with other mutagen, then used for obtained initial variety. 
DMS as a mutagen substantially higher in mutagen depression parameters induction in comparison with previous chemical mutagens and comparable with gamma-rays irradiated. We ranged mutagens in next sequence (from least to pick) $\mathrm{DAB} \rightarrow \mathrm{NEU} \rightarrow \mathrm{NMU} \rightarrow$ gamma-rays, DMS. We can predict numder of mutations at next generations on the level similar to gamma-rays.

To sum it up, DMS as a mutagen substantially stronger in chromosomal aberrations induction in comparison with previous chemical mutagens (DAB and nitrosoalkylureas) and compare with gamma-rays by its action on cells. We ranged mutagens in next sequence (from least to pick) $\mathrm{DAB} \rightarrow \mathrm{NEU} \rightarrow \mathrm{NMU} \rightarrow$ gamma-rays, DMS. We can predict high level of gens changes if we use DMS for mutation breeding purpose.

Repeated action of chemical mutagen doesn't lead to the same consequences for mutation varieties as recurrent action. There isn't any statistical significance difference between genotypes regarding method of breeding.

Comparing between bridges and fragments after DMS action confirmed reliability of fragments-bridges ratio (prevalence of fragments under bridges for chemical mutagens and opposite situation for gamma-rays) for mutagen nature identification, but for this mutagen other situation may observance in case of some genotypes $(0.9-1.0)$. In spite of other mutagens, for DMS genotypemutagen interaction has been shown in such way. In general, the rate of chromosomal aberrations is linearly increased with increase concentration of the mutagen.

\section{REFERENCES}

Albokari M., 2014. Induction of mutants in durum wheat using gamma irradiation. In: Pakistan Journal of Botany, 46, 317-324.

Bolzarn, A. D., Bianchi, M. S., 2006. Telomeres, interstitial telomeric repeat sequences, and chromosomal aberrations. In: Mutation Research, 612, 189 - 214.

Chaima, S., Girard, L., Ezzeddine, F., Pascale, G., 2012. Exposure of Vicia faba to sulcotrione pesticide induced genotoxicity. In: Pesticide Biochemistry and Physiology, 103, 9-14.

Jovtcheva, G., Stergiosa, M., Schubert, I., 2002. A comparison of N-methyl-Nnitrosourea-induced chromatid aberrations and micronuclei in barley meristems using FISH techniques. In: Mutation Research, 517, 47-51.

Juchimiuk-Kwasniewska, J., Brodziak, L., Maluszynska, J., 2011. FISH in analysis of gamma ray-induced micronuclei formation in barley. In: Journal of Applied Genetics, 52, 23-29.

Jankowicz-Cieslak I., Tai T. H., Kumlehn J., Till B. J., (Editors), (2017). Biotechnologies for Plant Mutation Breeding, International Atomic Energy Agency, Vienna.

Huaili Q., Lanming X., Fei H., 2005. Biological effect of the seeds of Arabidopsis thaliana irradiated by $\mathrm{MeV}$ protons. In: Radiation Effects \& Defects in Solids, 160, 131-136.

Karthika I R., Subba B., 2006. Effect of Gamma Rays and EMS on Two varieties of Soybean. In: Asian Journal of Biological Sciences, 5, 721-724.

Khaled, H., Anderson, D., Brinkworth, M., 2016. Detection of phase specificity of in vivo germ cell mutagens in an in vitro germ cell system. In: Toxicology, 16, 1-10. 
Lifang Y., Zengliang W., 2001. Radiobiological effects of a low-energy ion beam on wheat. In: Radiat Environ Biophys, 40, 53-57.

Mangi N., Baloch A. W., Arain S.M., Baloch M., Kandhro M.N., Abro T. F., BALOCH S. N., Mari S.N. (2016). Evaluation of Advance Mutant Genotypes and Interrelationship Analysis of Yield and Yield Associated Traits in Bread Wheat Genotypes. Sindh university research journal (Science Series), 48, 3, 783-786.

Natarajan, A.T., 2005. Chromosome aberrations: Plants to human and feulgen to FISH. In: Current Science 89, 335-340.

Nazarenko, M., 2016. Parameters of winter wheat growing and development after mutagen action. In: Bulletin of Transilvania University of Brasov - series II Forestry, Wood Industry, Agricultural, Food Engineering, 9 (58), 2, 109-116.

Nazarenko, M., Kharytonov, M., 2016. Characterization of wheat mutagen depression after gamma-rays irradiated. In: Agriculture and Forestry, 62, 4, 267-276.

Nazarenko, M., 2017. Specific Features in the Negative Consequences of a Mutagenic Action. In:Russian Journal of Genetics: Applied Research, 7, 2, 195-196.

Nazarenko, M., Lykholat Y., Grigoryuk I., Andrusevych K., 2017. Mutagen depression after recurrent chemical mutagen action at first winter wheat generation. In: Agriculture and Forestry. 63, 2, $161-170$.

Nazarenko, M., 2017. Influence of nitrosoalkylureas on winter wheat plants at first generation after mutagen action. In: Agriculture and Forestry, 63, 1, 319-328.

Nikolova, I., Georgieva, M., Kruppa, K., Molnor-Long, M., Liu, L., Manova, V., Stoilov, L., 2015. Cytogenetic effects in barley root apical meristem after exposure of dry seeds to lithium ion beams. In: Genetics and Plant Physiology, 5, $3-9$.

Özel, H.B., Kirdar, E., Bilir, N. 2015. The effects of magnetic field on germination of the seeds of oriental beech (Fagus orientalis Lipsky.) and growth of seedlings. Agriculture and Forestry, 61 (3): 195-206.

Rakhmatullina, E.M., Sanamyan, M.F., 2007. Estimation of efficiency of seed irradiation by thermal neutrons for inducing chromosomal aberration in $\mathrm{M}_{2}$ of cotton Gossypium hirsutum L. In: Russian Journal of Genetics 43(5), 518-524.

Rank, J., Lopez, L.C., Nielsen M.H., 2002. Genotoxicity of maleic hydrazide, acridine and DEHP in Allium cepa root cells performed by two different laboratories. In: Hereditas 136, 13-18.

Sanamyan, M. F., Petlyakoval, J. E., Sharipoval, E. A., Abdurakhmonov, I. Y., 2010. Morphological characteristics and identification of new monosomic stocks for cotton (Gossypium hirsutum L.) In: Advances in Bioscience and Biotechnology 1, 372-383.

Shu, Q.Y., Forster B.P., Nakagava H., 2011 Plant Mutation breeding and Biotechnology, Vienna, CABI publishing.

Zhang, J., Jiang, Y., Guo, Y., Li, G., Yang, Z., Xu, D., 2015. Identification of Novel Chromosomal Aberrations Induced by 60Co- $\gamma$-Irradiation in Wheat-Dasypyrum villosum Lines. In: International Journal of Molecular Sciences, 16, 29787-29796. 